Joanna Lustanski

DOI: $10.33896 /$ PorJ.2021.2.5

(McMaster University, Hamilton, Canada,

e-mail: lustansj@mcmaster.ca)

ORCID: 0000-0002-9346-364X

\title{
JAK MOŻNA BADAĆ POTOCZNĄ ŚWIADOMOŚĆ JĘZYKOWA
}

W naukach humanistycznych świadomość językowa jest nadal pojęciem „nieostrym, dość różnie rozumianym przez uczonych” [Cygan 2002, 52], choć poświęcono mu ostatnio wiele uwagi [np. Maćkowiak 2011; Miodunka 2017; Sagan-Bielawa 2014; Maćkowiak 2020]. W analizie tego zagadnienia nie wyklucza się „możliwości tworzenia nowych eksplikacji i poszukiwania kolejnych obszarów zastosowania tego pojęcia w praktyce analitycznej" [Wojtak, Siwiec 1999, 45]. Badania nad świadomością językowa podejmowano dotychczas nie tylko w zakresie typowych dziedzin językoznawstwa, takich jak socjolingwistyka czy psycholingwistyka, ale również w obrębie innych zakresów humanistyki, jak antropologia, psychologia czy socjologia. Do analiz świadomości językowej zazwyczaj wykorzystuje się istniejace teksty prasowe i ksiażkowe oraz wypowiedzi i opinie użytkowników języka zebrane metodą ankiet, wywiadów, grupowych dyskusji oraz rozmów $z$ częściowo kierowanymi pytaniami. Jednakże do tej pory nie wypracowano, przynajmniej na gruncie rodzimym, mniej lub bardziej precyzyjnych narzędzi badawczych, pewnego ustalonego akcesorium, według którego dany materiał językowy powinien podlegać analizie. ${ }^{1}$

Niniejszy artykuł jest próba przedstawienia takich narzędzi do badania świadomości językowej, a dokładniej rzecz ujmując - do badania poziomu tej świadomości. Propozycje wyznaczników przedstawił amerykański językoznawca Dennis R. Preston w obszernym artykule Whaddayaknow? The Modes of Folk Linguistic Awareness [1996]. Jego tezy zostały następnie zrewidowane i rozbudowane w ksiażce pt. Folk Linguistics [2000], która napisał wspólnie $z$ Nancy A. Niedzielski. Niniejszy artykuł nie jest tłumaczeniem $z$ języka angielskiego, lecz rekapitulacją najważniejszych założeń badawczych zawartych w powyższych publikacjach oraz próbą wstępnej odpowiedzi na pytanie, czy wyróżniki świadomości językowej w rozumieniu D.R. Prestona mogłyby znaleźć zastosowanie w badaniach nad świadomością językową użytkowników polszczyzny.

1 Novum stanowią badania zespołu K. Kłosińskiej, w których jasno wyznaczono szereg kodów jako narzędzi badawczych służących do analizy postaw wobec współczesnego języka polskiego i norm językowych [Kłosińska et al. 2017]. 


\section{RODZIME UJĘCIA ŚWIADOMOŚCI JĘZYKOWEJ}

W celu lepszego zrozumienia, na czym polega specyfika taksonomii D.R. Prestona, należy krótko scharakteryzować pojęcie świadomości językowej funkcjonujące w polskiej literaturze naukowej oraz omówić tradycyjnie przyjmowane poziomy tej świadomości. Według podstawowych źródeł encyklopedycznych świadomość językowa jest to

ogół poglądów jednej osoby, grupy społecznej lub szerszej zbiorowości na język, a także ogół postaw wobec niego i emocji z nim związanych,

a obejmuje ona:

1. Wiedzę o języku (intuicyjna, szkolną, rzadziej naukowa); 2. Kompetencje językowa, czyli zdolność do właściwej selekcji środków językowych, adekwatnych do celu wypowiedzi, jej charakteru, stylu, adresata; oraz 3. Ocenę ich akceptowalności fonetycznej, gramatycznej, logicznej, kulturowej itd., czyli poczucie językowe [Urbańczyk, Kucała 1999, 394].

Zdaniem E. Sękowskiej w językoznawstwie polskim można zasadniczo wyróżnić trzy podejścia do świadomości językowej: 1) psychologiczne, które pozwala utożsamiać świadomość $z$ wiedzą idealnego użytkownika języka, a więc traktować ja jako synonim kompetencji językowej; 2) społeczne, w którym świadomość językową uważa się za składnik kompetencji komunikacyjnej oraz 3) praktyczne, które zbliża pojęcie świadomości do pojęcia sprawności językowej [Sękowska 1996, 9]. Bardziej szczegółową stratyfikację podaje K. Maćkowiak, wyróżniając pięć ujęć charakterystyki pojęcia świadomości językowej, m.in.: normatywne, opisowo-rejestrujace, psycholingwistyczne, socjolingwistyczne, kulturowo-antropologiczne [Maćkowiak 2011].

W polskiej socjolingwistyce wyszczególnia się ponadto warstwy świadomości językowej. Najbardziej rozpowszechnione wyróżnienie zostało wprowadzone przez A. Markowskiego [Markowski 2008a, 220-222]. Według badacza poziom podstawowy utożsamiany jest $z$ intuicja językowa, subiektywnym poczuciem użytkownika języka przy wyborze konkretnych form. Intuicja językowa zwykle zawiera nieco świadomości estetycznej, która przejawia się w używaniu sformułowań typu "razi mnie” bądź „brzmi obco”. Sa to zatem sądy oraz przekonania pojawiające się bezpośrednio, bez świadomego operowania przesłankami, w których rozumowanie odbywa się bez uświadamiania sobie procesu dochodzenia do rozwiazania problemu.

Objawem wyższego poziomu świadomości językowej jest „wygłaszanie sądów językowych, związanych $z$ koniecznością wyboru między różnymi elementami językowymi i ocena tych elementów" [Markowski 2008b, 124]. Ta płaszczyzna świadomości wiąże się $z$ odwoływaniem do podstawowej wiedzy o języku, np. tej zdobytej w szkole (nauczyciele traktowani 
sa jako autorytet w dziedzinie kultury języka), oraz do codziennej komunikacji zachodzacej na określonym terytorium geograficznym. Do tego poziomu można zaliczyć również postawy oparte na wiedzy zdroworozsądkowej - tak jak ujmuje je S. Dubisz [Dubisz 2017, 304] - które sięgają do zasobów wiedzy potocznej, a nie tylko szkolnej wiedzy językowej.

Najwyższy poziom świadomości językowej wymaga od użytkownika języka znajomości jakiegoś kryterium oceny (np. uzusu) i odwoływania się do niego. Jest to zwiazane $z$ sądami językowymi uzasadnianymi merytorycznie, np. ktoś wybiera wyraz rodzimy, a nie obcy, formułuje regułę. W ujęciu S. Gajdy istnieja trzy płaszczyzny tzw. językowej samowiedzy:

1) poczucie językowe - raczej intuicyjny ogląd praktyki komunikacyjnej i fragmentaryczne uświadomienie sobie niektórych jej stron; 2) potoczna świadomość językowa znacznie wyższy stopień samowiedzy, mniej lub bardziej rozbudowanej, co zależy od wielu różnorodnych czynników; 3) naukowa wiedza o komunikacji językowej - wiedza nie pozbawiona luk, o różnym stopniu głębokości, uzyskana w toku procesu badawczego w wielu dyscyplinach, które zajmuja się ludzkim porozumiewaniem się (m.in. lingwistyka, psycholingwistyka, teoria komunikacji, teoria tekstu, filozofia, semiotyka, naukoznawstwo) [Gajda 1994, 229].

W świetle socjolingwistyki polskiej świadomość językowa jest wytworem ludzkiego rozumu, wynikiem życia w społeczeństwie, pewna postawą wobec czegoś. Przedmiotem badań prowadzonych zwykle na pograniczu kultur i odmian języka sa dane „przefiltrowane” przez ludzkie doświadczenie, a w analizach materiału nieodzowne sa odwołania do świadomości społecznej i wartościowania kulturowego, jakie ta świadomość narzuca [zob. np. prace H. Kurek, H. Pelcowej, S. Cygana, M. Sagan-Bielawy]. Definicje świadomości językowej oraz jej stratyfikacje w ujęciu A. Markowskiego i S. Gajdy jako punkt wyjścia obierają klasyczne w filozofii oraz innych naukach typy poznania przedmiotu, jakimi sa intuicja i wiedza (potoczna, szkolna, naukowa). W ujęciach tych - jak dotychczas - niewiele miejsca poświęcono dwóm innym perspektywom badawczym: po pierwsze, tzw. nosicielom świadomości językowej, czyli przeciętnym użytkownikom języka, oraz po drugie, wyróżnikom samej świadomości językowej.

\section{ŚWIADOMOŚĆ JĘZYKOWA W LINGWISTYCE ZACHODNIOEUROPEJSKIEJ I AMERYKAŃSKIEJ}

W językoznawstwie zachodnioeuropejskim pojęcie świadomości językowej ma inny zakres i zastosowanie. Według Dictionary of Linguistics and Phonetics pod red. D. Crystala [2001] termin ten stosowany jest przede wszystkim w językoznawstwie szkolnym, a odnosi się do reakcji na użycie języka, która ma charakter przemyślany, responsywny (w sensie 'wyczulony na język') i krytyczny. W zakres świadomości wchodzi też uświadamianie sobie istnienia odpowiedniej terminologii, czyli świado- 
mość metajęzykowa. ${ }^{2}$ Zdaniem R. Cartera [2003] świadomość językowa odnosi się do rozwijania w mówiących zdolności uprzytamniania sobie, jak działaja formy i funkcje języka oraz kształtowania wrażliwości na sprawy związane $z$ językiem. Podobnie jak D. Crystal, R. Carter podkreśla, że pojęcie świadomość językowa odnoszone jest zwykle do procesu nabywania drugiego lub obcego języka, a w stosunku do języka pierwszego preferowanym terminem jest często wiedza o języku. Badania nad świadomością językowa maja długa tradycję w krajach zachodnioeuropejskich, ${ }^{3}$ należąc do dydaktyki wielojęzyczności, której celem jest integracja w klasie uczniów posługujących się różnymi językami lub dialektami w kontekście pozalekcyjnym oraz uświadamianie im wielojęzyczności społeczeństw np. Unii Europejskiej [zob. Gębal 2013, 52-55]. W ostatnich dekadach badania nad świadomościa językową zaczęły wykraczać poza wąsko rozumiane analizy na poziomie zdania indywidualnego użytkownika języka, by obejmować zagadnienia dyskursu całych grup społecznych. Tak ukształtowała się tzw. Critical Language Awareness (CLA), według której język nie jest nigdy neutralny, ale zawsze stanowi część napięć społecznych, w których może ukrywać się, lub ujawniać, społeczna i ideologiczna natura tekstów [Fairclough 1992].

Na gruncie amerykańskim świadomość językowa stanowi jedno z zasadniczych zagadnień dialektologii percepcyjnej - dziedziny badającej postrzeganie dialektów i zróżnicowanie dialektalne przez niefilologów. Ta gałaź amerykańskiej socjolingwistyki jest w Polsce dotychczas mało znana [Stachowski 2018; Bounds 2015], chociaż prezentuje ciekawa perspektywę badawcza, niewykorzystana jeszcze na gruncie polskiego językoznawstwa. W ujęciu D.R. Prestona, którego uznaje się za ojca dialektologii percepcyjnej, świadomość językowa to stopień uzmysłowienia sobie, jaki maja przeciętni użytkownicy języka w odniesieniu do niego ${ }^{4}$ [Preston 1996; Niedzielski, Preston 2000]. Pojęciu przypisuje się określenie folk, które można w tym kontekście tłumaczyć jako 'potoczny'. ${ }^{5}$ W definicji tej zasadnicze jest wyróżnienie czynnika nosicieli świadomości językowej, co - jak dowodzi D.R. Preston - jest istotne $z$ punktu widzenia zawartości świadomości. Zasadniczy podział przebiega między specjalistami językowymi (językoznawcami i specjalistami pokrewnych dziedzin,

${ }^{2} \mathrm{~W}$ oryginale: „Language awareness: a term used especially in educational linguistics, to refer to an informed, sensitive and critical response to the use of language by oneself and others, including the awareness of relevant terminology ('metalinguistic awareness')" [Crystal 2001, 215].

${ }^{3}$ O czym świadczy na przykład istnienie renomowanego czasopisma lingwistycznego „Language Awareness” oraz współpracującego z nim stowarzyszenia Association of Language Awareness [zob. van Essen 1997].

4 W oryginale: „I mean, by 'awareness', the 'degree' of consciousness nonlinguists have in general about language" [Preston 1996, 72].

5 Rozważania nad tłumaczeniem określenia folk na francuski i niemiecki w artykule Paveau 2007. 
np. filologami) a niespecjalistami, których można nazwać „językoznawczymi laikami". Innymi słowy, niespecjaliści to przeciętni użytkownicy języka, którzy nie mają wykształcenia lingwistycznego. ${ }^{6}$ U specjalistów poziom świadomości językowej jest pogłębiony, oparty na naukowej wiedzy o języku, podczas gdy świadomość językowa niefilologów opiera się w dużym stopniu na intuicji językowej, samowiedzy i potocznej wiedzy o świecie. Warto w tym miejscu podkreślić, że świadomość językowa dotyczy każdego użytkownika języka, nie można zatem powiedzieć, że ktoś, kto reaguje na jakiś problem językowy, rozważa go oraz podejmuje jakąś językowa aktywność, jest „nieświadomy”, chyba że żaden poziom potocznej świadomości językowej nie jest mu dostępny. Świadomość językowa przeciętnego użytkownika języka nazywam potoczna ${ }^{7}$ świadomościa językowa (folk-linguistic awareness).

\section{WYRÓŻNIKI POTOCZNEJ ŚWIADOMOŚCI JĘZYKOWEJ}

Na podstawie wielu badań metodą ankiet oraz wywiadów środowiskowych D.R. Preston zbudował systematykę wyróżników potocznej świadomości językowej, na które składa się: 1. dostępność (availability), 2. trafność (accuracy), 3. szczegółowość (detail) oraz 4. umiejętność kontrolowania różnych wariantów języka (control). Niektóre z przykładów użytych przez badacza moga być w pewnym stopniu niezrozumiałe dla językoznawców niespecjalizujacych się w lingwistyce angielskiej, ${ }^{8}$ dlatego w niniejszym artykule przedstawiam charakterystykę konceptów D.R. Prestona przy użyciu przykładów analogicznych, lecz pochodzących z rodzimych źródeł. Stanowia je polska literatura językoznawcza, bogata w egzemplifikacje, oraz własne materiały językowe ekscerpowane wśród polskiej grupy etnicznej w Kanadzie. $\mathrm{Na}$ materiały te składaja się nagrania rozmów prowadzonych $\mathrm{z}$ reprezentantami generacji imigracyjnej i polonijnej, komentarze do postów językowych zamieszczanych w zamkniętych grupach polonijnych na Facebooku, ${ }^{9}$

6 Próby podziału nosicieli świadomości językowej na grupy specjalistów oraz niespecjalistów podejmowano już wcześniej. Na gruncie lingwistyki polskiej po raz pierwszy wprowadził to rozróżnienie Jan Baudouin de Courtenay [Baudouin de Courtenay 1915].

7 K. Maćkowiak [2020] wyróżnił dwie podstawowe odmiany świadomości: potoczna (spontaniczna, intuicyjna) oraz naukowa (systematyczną, oceniana w kategoriach prawdy lub fałszu).

8 Na przykład gdy mowa o przemianach socjolingwistycznych zachodzacych w mniej znanych odmianach języka angielskiego, jak African American Vernacular English (AAVE). Warto dodać, że autorka artykułu prowadziła przez kilka lat wykłady $z$ socjolingwistyki na wydziale lingwistyki McMaster University w Kanadzie.

9 Chodzi o następujace grupy: „Polki w Kanadzie” (139 komentarzy udzielonych przez 76 uczestniczek dyskusji); „Polonia Kanada News” (65 komentarzy 
jak również gromadzone - przez prawie dwie dekady - zbiory obserwacji zachowań językowych. Celem wprowadzenia polskiej egzemplifikacji, która $\mathrm{w}$ każdym wypadku jest porównywalna $z$ oryginałem, jest zilustrowanie przedstawianych konceptów, niekoniecznie zaś udowodnienie, że systematyka D.R. Prestona ma charakter uniwersalny.

\section{Dostępność}

Nie wszystkie cechy językowe lub fakty językowe, niezależnie od tego, czy dotyczą wykonania językowego (performancji), zdolności mówienia (kompetencji) czy po prostu reakcji na język, są dostępne świadomości przeciętnego użytkownika języka w tym samym stopniu. Zdaniem D.R. Prestona można wskazać elementy a) niedostępne, b) dostępne, c) elementy poddajace się sugestii oraz d) elementy typowe.

a) Do elementów niedostępnych świadomości potocznej należą specyficzne cechy fonologiczne, których przeciętny użytkownik języka nie zauważa. Na przykład wymowa par wyrazowych kopie (3. os. 1. poj. czasownika kopać) - kopie (mianownik 1. mn. rzeczownika kopia) czy też wiedzie - wjedzie. Choć nie ulega watpliwości, że pary te sa przez niektórych Polaków rozróżniane w wymowie i percypowane jako odrębne formy [zob. Dunaj 1991], to jednak nie spotkałam się do tej pory $z$ dyskusja nielingwistów na temat tego, czy $p$ lub $w$ to fonemy miękkie, czy też obecnie obowiazuje wymowa asynchroniczna, innymi słowy, czy system $z$ usuniętymi palatalnymi fonemami wargowymi trzeba uznać za dominujący we współczesnej polszczyźnie. Istnieja ponadto pewne cechy fonologiczne języka, które są obecne w świadomości przeciętnego mówiącego, aczkolwiek sa trudno dostępne i wydobywane tylko wtedy, gdy badacz je wskaże i opisze. Do takich elementów należy angielskie tzw. ciemne $l$ (dark l), ${ }^{10}$ przy wymowie którego tylna część języka jest uniesiona $\mathrm{w}$ stronę podniebienia miękkiego (velum), dając mu zabarwienie przypominające polskie sceniczne [1]. Osoby władające nawet biegle angielskim i polskim często nie są świadome interferencji ciemnego $l \mathrm{w}$ wymowie polskiej, dopóki jej się im nie wskaże. Na przykład prowadząc nagrania różnych odmian polszczyzny używanej w Kanadzie, miałam do czynienia ze studentkami mówiącymi biegle po polsku, ale które wymawiały słowo kowal z angielska. Dopiero po odsłuchaniu nagrań i wskazaniu tej cechy fonetycznej studentki zauważyły różnicę i „pilnowały” swojej wymowy w czasie kolejnych nagrań.

b) Przeciętny użytkownik języka może rozmawiać na temat zagadnień wskazanych przez badacza, ale jeśli detale omawianego problemu nie zo-

autorstwa 57 osób); „Polonia Edmonton News” (17 komentarzy, 13 osób zabrało głos w dyskusji).

$10 \mathrm{~W}$ kanadyjskim angielskim alofon ten pojawia się w wygłosie oraz przed spółgłoską. 
staną wprowadzone do rozmowy, niefilolog zwykle nie sięga do innych, dostępnych mu zasobów świadomości językowej. Dobrze obrazuje to dyskusja w grupie fejsbukowej „Polki w Kanadzie”. W jednym $z$ wątków na temat języka polskiego używanego w Kanadzie ${ }^{11}$ zdecydowana większość komentarzy ograniczyła się do leksyki lub dość ogólnych spostrzeżeń na temat polszczyzny będącej pod silnym wpływem języka angielskiego. Oto przykłady:

Ważne że rozumiem ... nie wierzę że tak mówią specjalnie ... to się poprostu miesza ... ja też tak czasem mówię ... czasem słowo mi poprostu nie pasuje. Np idę do bejsmentu wstawić pranie bo przecież nie do piewnicy hihi. ${ }^{12}$

To ja jeszcze dodam, mnie denerwuje jak oglądam telewizje $z$ Polski i słyszę jak się używa słów pochodzących $z$ angielskiego. Zgadzam się że są rzeczy pochodzące z Ameryki odnoszące się do specyficznych sprawy jak np komputerów ale „imidz” to mi strasznie nie pasuje. Chociaż....w języku polskim zawsze były słowa pochodzące $z$ innych, np żydowskiego, łaciny, niemieckiego, czy francuskiego. Widocznie taka ewolucja.

c) Potocznej świadomości językowej dostępne są też elementy podatne na sugestie. $\mathrm{W}$ tym samym wątku jedna $z$ internautek zamieściła wpis: „To mój syn i jego polski”, do którego dołączyła zrzut z ekranu telefonu: „Auto nie jedzie, Co znim moze bycz? Olej byl Dolany? Bo dym leczi z szylnika", co inna internautka zripostowała:

Radzi sobie chłopak. Można zrozumieć. Moja córka też miesza języki albo zapomni słów. Któregoś dnia zapytała babcię: „babcia! Kiedy zdechła twoja mama”. Wtenczas nie znała słowa „umarła”. No cóż!

Filolog bez trudu zauważy, że w tekście SMS-a nie ma mieszania języków, a jedynie ${ }^{13}$ mieszanie zapisów graficznych szeregów spółgłosek zwarto-szczelinowych i szczelinowych z miękkimi: $c z-c ́ c c i, s z-s i$. Pani udzielająca odpowiedzi zwiedziona została ta pozorna, lecz ostra wizualnie niepoprawnością ortograficzną polszczyzny i w odpowiedzi posłużyła

11 Oto treść wątku: „Dziewczyny, usłyszałam niedawno takie zdanie: "Zastopował mnie kop i zaczardżował za speeding”. Co myślicie o tym, jak mówią Polacy mieszkajacy w Kanadzie? Jakie sa wasze opinie?”.

12 W cytatach wprowadziłam korektę najbardziej ewidentnych usterek graficznych: usunęłam zbędne przerwy, poprawiłam literówki (np. prwda na prawda), zmieniłam użycia dużej litery I na oznaczenie spójnika $i$, wprowadziłam polskie znaki diakrytyczne, których zdecydowana większość uczestników polonijnych forów społecznościowych nie stosuje. Błędy ortograficzne, słownikowe, interpunkcyjne oraz brak polskich znaków zostawiłam w wersji oryginalnej.

13 Można ewentualnie zauważyć pewną nienaturalność wyrażenia co z nim może być, które może być traktowane jako kalka składniowa angielskiej struktury what's with something, ale ze względu na obecność zaimka nim wyrażającego zgodę rodzajową $z$ podmiotem auto, a nie tym $\mathrm{w}$ zdaniu, można powiedzieć, że jest to eliptyczna forma wyrażenia co z nim może być [nie tak]. 
się przykładem z pogranicza leksyki i semantyki, który wskazuje na inny rodzaj zagadnień dotyczących języków w kontakcie.

d) Oprócz elementów niedostępnych, dostępnych oraz poddających się sugestii istnieja jeszcze elementy typowe, które dotyczą tego, co powszechne, utarte, znane $z$ doświadczeń społeczno-kulturowych:

Czasem jest po prostu prościej wtrącić ang słówko zamiast polskiego. Łatwiej zapytać męża czy wykupił car insurance niż ubezpieczenie na samochód.

Słyszałam kiedyś rozmowę Hindusów a co jakiś czwarty wyraz był po angielsku...więc nie tylko my to robimy... więc czym się przejmować...normalka...

Osobiście mi to nie przeszkadza. Szybciej czasami jest wtrącić jakieś słowo po angielsku już po polsku bo tu mieszkamy i żyjemy...I tak wszyscy $z$ nas to rozumieją. Ale faktycznie ...brzmi czasem śmiesznie.

Typowe elementy dostępne potocznej świadomości językowej nosicieli języka polonijnego można widzieć jako stereotypowe, zbanalizowane stwierdzenia na temat mowy imigrantów. W tym wypadku sa one powielane, powtarzane bezrefleksyjnie, stanowiac niekiedy usprawiedliwienie określonych zachowań językowych.

\section{Stopień trafności}

Potoczne opisy języka, będące wyrazem świadomości językowej lingwistycznego laika, moga być trafne lub nie. Trafność jest u D.R. Prestona rozumiana nie jako poprawność, która zakłada wartościowanie, ale jako odrębna kategoria $z$ zakresu tzw. lingwistyki potocznej (folk linguistics), według której przeciętny użytkownik języka postrzega i opisuje język własnymi kategoriami, które nie sa gorsze od kategorii ustalonych w językoznawstwie, lecz po prostu inne. W odniesieniu do kryteriów poprawności językowej są one zatem bardziej lub mniej trafne. W komentarzach językowych na portalu „Polki w Kanadzie” pojawiły się na przykład następujące opinie:

wtrącanie słówek angielskich to nie to samo co przekształcanie języka angielskiego inszura itp.

Mam też koleżankę, która urodziła się tutaj i tutaj mieszka całe życie i naprawdę mówi pięknie po polsku. Czasami nie zna polskiego słowa i wkłada angielskie ale nie tworzy nowych wyrazów.

W mowie - moge jakoś przeżyć jak ktoś (albo ja P) wtrąca angielskie słówka. Spolszczone wersje angielskich słów drażnią mnie mocno. Ale w pisowni... albo pisze po polsku, albo po angielsku - i nie ma przebacz, i wszelkiego rodzaju „kary” i „katyge” doprowadzaja mnie do szału. 
Wypowiedzi te świadczą o tym, że wśród melanżu jednostek leksykalnych dialektu polonijnego przeciętni użytkownicy języka zauważaja różnice między różnymi elementami języka, w tym wypadku cytatami a wyrazami adaptowanymi, oraz że trafnie potrafią zobrazować swoje opinie przykładem. W ostatnim przykładzie celne jest spostrzeżenie dotyczące znacznej różnicy między odmianą mówioną a odmianą pisaną języka polonijnego. O ile bowiem odmiana mówiona cechuje się znacznym liberalizmem w doborze środków językowych, o tyle odmiana pisana jest zwykle bardziej zachowawcza. Ponadto nie ma reguł pisowniowych ustalonych dla powszechnych w mowie elementów języka polonijnego, a różne sposoby ich zapisu na portalach społecznościowych rażą obcościa, np. cottage bywa polonizowany następujaco: kotycz, katycz, katydiz, katyge. Notabene, interesujace byłoby zbadanie, czy używanie cytatów angielskich spotyka się $z$ większą aprobata mówiących niż powszechne w polszczyźnie polonijnej adaptacje fonetyczne i fleksyjne które $z$ punktu widzenia systemu językowego sa dowodem na oswojenie obcych form i powiększenie zasobu leksykalnego języka, a zatem bardziej pożądane - czy też wręcz przeciwnie.

Trafność sądów cechujących potoczną świadomość językowa jest determinowana przez doświadczenie społeczne i kulturowe, które zależy od wielu różnych czynników. Oto dwie kontrastujące opinie na temat kanadyjskiej odmiany polszczyzny:

najczęściej mówią tak ci co niedawno tu przyjechali... ma to być pewnego rodzaju popisywanie się...

Ja kumam u ludzi, którzy długo mieszkają w Kanadzie i ang się posługują, No ale jak mi cwaniak $z$ zerowa znajomością angielskiego w rozmowie ze mna twierdzi, że on hedik ma, tam sa kakrocie albo jak widzę tu pisane katycz to autentycznie grabki mi opadaja.

Zdaniem pierwszej internautki nasycenie języka jednostkami polonijnymi dotyczy mowy nowo przybyłych do Kanady, którzy chca się popisać znajomością tutejszych obyczajów językowych, wtopić się szybko w nową rzeczywistość. Dla drugiej internautki jednak używanie dialektu polonijnego jest usprawiedliwione w wypadku rodaków o długim stażu imigracyjnym, dla których ta odmiana polszczyzny stała się kodem codziennego porozumiewania się. Trudno rozstrzygać o trafności tych dwóch opinii, bo to, kiedy imigrant zaczyna mówić dialektem polonijnym, zależy od wielu czynników, jak chociażby od poziomu wykształcenia i znajomości obu języków będących w kontakcie, związku emocjonalnego $z$ krajem pochodzenia, a nawet ogólnej wrażliwości na język. Do czynnika znajomości języka kraju osiedlenia odwołuje się zresztą druga wypowiedź, piętnująca snobizm językowy polegający na wtrącaniu słówek angielskich przez osoby nieznające tego języka lub znające go w stopniu minimalnym. 
O częściowej trafności sądu językowego można mówić w odniesieniu do innej wypowiedzi:

są wyrazy które zastępuję słowami angielskimi, a dotyczy to głównie słów mało popularnych, albo kompletnie nieistniejących, kiedy mieszkałam w Polsce.

Powyższa opinia ma częściowe uzasadnienie w rzeczywistości, bo wiele leksemów zostaje zastapionych angielskimi odpowiednikami, jednakże $z$ badań nad leksyka polonijną wynika, że choć adaptacje moga być podyktowane potrzeba nazwania nowych desygnatów, to jednak frekwencja oraz regularność zapożyczeń w pewnych grupach znaczeniowych (centrach tematycznych) moga być czynnikami przeważającymi w procesie przejmowania anglicyzmów do języka polskiego imigrantów [Sękowska 1994; 2008].

\section{Poziom szczegółowości}

Trzecim wyznacznikiem potocznej świadomości językowej D.R. Prestona jest szczegółowość. W świadomości językowej niespecjalisty element języka może być opisywany według kontinuum: od charakterystyki bardzo ogólnej do charakterystyki dość szczegółowej. Na przykład dużą dozę ogólności zawierają następujące refleksje językowe:

ja tez tak często mieszam dwa języki....przez jakiś czas starałam się hamować i uważać ale to jest silniejsze ode mnie.

Każdej z nas się zdarza połączyć angielski i polski w jedna sentencji.

Cytaty te sa tylko ogólnym komentarzem do wątku na temat leksyki polonijnej i ograniczają się do stereotypowego stwierdzenia o mieszaniu dwóch języków. Powierzchowne refleksje snuje też inna internautka:

Moja obserwacja: W Polsce zauważam więcej wtrąceń $z$ języka angielskiego niż wśród Polonii kanadyjskiej. Widać to i słychać na codzień w mediach, na ulicy, u małych dzieci i starców, w miastach i w najmniejszych zakątkach wiejskich... 35 lat temu język polski wśród Polonii był bardziej „zanieczyszczony” naleciałościami z angielskiego niż ten używany przez rodaków w PL. Dzisiaj język polski w Polsce jest bardziej zniekształcony niż używany przez Polonię 35 lat temu.

$Z$ drugiej strony, w świadomości potocznej istnieją sądy, które charakteryzuje znaczny stopień szczegółowości. Oceniając leksykę polonijna, pewna internautka szczegółowo objaśnia, że użycie konkretnych jednostek polonijnych zależy od typu interlokutora oraz sytuacji komunikacyjnej, w której się znajduje:

Myślę, że to naprawdę zależy $z$ kim rozmawiamy. Ja mogę powiedzieć do męża 'trafik' ale do obcej osoby powiem 'korek'. Tak samo jest $z$ moimi dziećmi. Do nich mówię 
'wyrzuć to do śmieci' a mężowi mówię, że 'jutro jest garbage day' kiedy trzeba śmieci wystawić. $Z$ kumpelami możemy sobie żartami mówić i nie ma w tym nic złego. ${ }^{14}$

Ponadto pewnym stopniem szczegółowości odznacza się poniższa wypowiedź piętnująca bezrefleksyjne używanie spolszczonych leksemów angielskich:

Nagle zapomnieli, że można jeździć autostradą (a nie „hajłejem”), jeść krewetki (a nie „szrimpy”) i wyrzucić śmieci do śmietnika (a nie „garbicza”) :)

Stopień szczegółowości w opisywaniu danej cechy językowej wydaje się ściśle związany z poziomem świadomości językowej niefilologa: im lepsza umiejętność posługiwania się językiem (powyższe dwa cytaty cechuje dość znaczna poprawność gramatyczna i interpunkcyjna, choć $\mathrm{w}$ oryginalnym zapisie brakowało polskich znaków diakrytycznych), lepiej rozwinięta sprawność porównywania i analizy języków oraz uświadamiania sobie sytuacyjnego i socjokulturowego uwarunkowania działań językowych, tym więcej detali pojawia się w wyrażanej refleksji.

\section{Umiejętność kontrolowania różnych wariantów języka}

W taksonomii D.R. Prestona czwartym wymiarem potocznej świadomości językowej jest umiejętność kontrolowania różnych wariantów języka lub różnych języków. Zarówno w mówieniu o języku (czyli w świadomości metalingwistycznej), jak i w wykonaniu językowym mówiący może, choć nie musi, mieć kontrolę nad różnymi wariantami języka będącego przedmiotem rozważań. Przeciętny użytkownik języka, który potrafi wyrażać się tylko ogólnie o jakimś innym języku, może mieć znaczną zdolność naśladowania tego języka. Polki w Kanadzie tak opisują swoje umiejętności kontrolowania znanych im odmian języka ojczystego:

Będąc w Polsce staram się być bardziej polska, niż nasi rodacy... mimo to zdarzają się wpadki... Dzwonię do firmy, pytam o właściciela...oświadczam, że wczoraj zostawiłam message .... na to pan miłym głosem „szefa nie ma , ale ja mam klucz do jego pokoju i mogę sprawdzić czy to tam jest".

I mimo, że mieszkam w kanadzie prawie 30 lat, w polsce będąc nie wcinam w ogóle angielszczyzny i ludzie są pod wrażeniem, że mówię tak, że nigdy by nie wyczuli, że nie mieszkam w polsce.

14 Powyższa wypowiedź jest znamienna, bo pokazuje również świadomość roli, jaką odgrywa matka, w kształtowaniu poprawnych wzorców językowych u dziecka. Zdaniem W. Miodunki [2020] na świadomość językowa najbardziej wypływaja inni ludzie, począwszy od członków rodziny. 
Wypowiedzi te pokazuja pewne ogólne strategie, do których uciekaja się przeciętni mówiący w celu kontrolowania języków. Deklarują wyraźnie, że staraja się pilnować czystości języka polskiego podczas pobytów w Polsce, unikać angielszczyzny, tak aby rodacy nie zorientowali się, że rozmawiaja $z$ Polakiem żyjacym od dawna poza Krajem. W dużym stopniu taka samokontrola językowa jest możliwa, ale niewątpliwie ma swoje ograniczenia, co pokazuje przykład internautki dotyczacy nieopatrznego użycia słowa message.

\section{RELACJE MIĘDZY WYZNACZNIKAMI POTOCZNEJ ŚWIADOMOŚCI JĘZYKOWEJ}

Powyższe wyznaczniki potocznej świadomości językowej mogą tworzyć kontinua, chociaż - jak zastrzega D.R. Preston - dostępność i umiejętność przełączania między wariantami można by również uznać za odrębne kategorie, a stopień trafności i stopień szczegółowości moga być traktowane dychotomicznie. Wszystkie te wymiary potoczności sa relatywnie niezależne od siebie, co oznacza, że usytuowanie opinii o danej cesze językowej na jednym $z$ kontinuów nie determinuje jej pozycji na innym kontinuum.

Relację między dostępnością a trafnością dobrze ilustruje anegdota opisana przez L. Bloomfielda [1944]. Badacz ten, specjalizujacy się m.in. w językach rdzennych Indian, opisał rozmowę $z$ lekarzem, który twierdził, że język Chippewa zawiera tylko kilkaset słów i na potwierdzenie swoich słów przywołał opinię przewodnika pochodzacego z plemienia Chippewa. Kiedy L. Bloomfield próbował zaprzeczyć i objaśnić, że jest inaczej, lekarz krótko i z pewna niechęcia powtórzył swoją opinię, po czym odwrócił się plecami. ${ }^{15} \mathrm{Z}$ tej anegdoty wynika, że chociaż pojęcie języka Chippewa jest dostępne przeciętnemu użytkownikowi języka do komentowania, widać wyraźnie, że brakuje mu trafnych, dokładnych (akuratnych) informacji na temat tego języka.

Podobnie rzecz ma się z relatywną niezależnością między kategoriami dostępności a szczegółowości, która D.R. Preston opisuje, odwołując się do przykładów rozmów o obcych akcentach. Podkreśla, że przeciętny użytkownik języka zwykle zauważa obcy akcent i potrafi go skomentować, ale kiedy zostanie poproszony o przykład, raczej nie będzie umiał go wskazać. $Z$ moich obserwacji językowych wśród różnych grup etnicz-

15 W oryginale: „A physician of good general background and education ... told me that the Chippewa language contains only a few hundred words. Upon question, he said that he got this information from his guide, a Chippewa Indian. When I tried to state the diagnostic setting, the physician, our host, briefly and with signs of displeasure repeated his statement and then turned his back on me" [Bloomfield 1944, 49]. 
nych, w tym Polonii kanadyjskiej, wynika, że obiegowa opinia o francuskim używanym w prowincji Quebec jest taka, iż jest to odmiana niezrozumiała, lub zrozumiała w małym stopniu, dla mieszkańców Francji. Podobny pogląd wyraziła też jedna $z$ internautek:

To jest też tak, $z$ własnego doświadczenia w Quebec ludzie myślą, ze mówią po francusku, ale prawda jest taka, że Francuzi z Francji nie rozumieją francuskiego $z$ Quebec.

Wpis ten spotkał się z następującą ripostą:

Oni się swobodnie dogadaja tylko québécois mówia językiem 'luźnym' i mają inny akcent. Moja córka w tym roku miała nauczyciela $z$ francji i mówiła, że on mówił tak ładnie, bardziej formalnie. Ale rozumiała jego tak samo jak tutejszych nauczycieli.

Jak widać, przeciętnemu użytkownikowi języka trudno jest wskazać konkretne szczegóły, którymi charakteryzuje się kanadyjski francuski, choć można powiedzieć, że ta odmiana języka francuskiego jest dostępna świadomości mieszkańców Kanady, gdyż jest drugim językiem oficjalnym tego kraju.

Kategoria dostępności może być też niezależna od kategorii umiejętności przełączania między wariantami języka. Kilka lat temu moje, wówczas sześcioletnie, dwujęzyczne dziecko, wychowujące się w Kanadzie, przebywało w Polsce na wakacjach. Podczas wizyty u przyjaciół obecne tam dzieci prosily cierpliwie „powiedz coś po angielsku”, na co speszona dziewczynka po dłuższej chwili milczenia zareagowała: „tu nikt tak [po angielsku] nie mówi”. Oznacza to, że w pewnych sytuacjach mówiący nie potrafią kontrolować (zmieniać kodu językowego na żądanie) wariantu językowego, w którym są biegli, ponieważ kontekst może nie być odpowiedni. ${ }^{16}$

Relacja między trafnością a szczegółowością odnosi się do faktu, że charakterystyka danej cechy językowej, której dokonuje niespecjalista, może być szczegółowa lub ogólna i w każdym $z$ tych wypadków - trafna lub nietrafna. Na przykład w czasie prób jednego $z$ polonijnych dziecięcych zespołów wokalnych w Toronto dyrektor często zwraca chórzystom uwagę, mówiąc „nie sepleńcie”. Ma wówczas na myśli, powszechne w mowie poko-

16 Analogiczny przykład podaje D.R. Preston [1996, 42-43]: „In some cases, respondents are not even able to control (i.e. perform on demand) a variety which they claim to be proficient speakers of because the setting or context is not right. After A claims to be a proficient speaker of African-American Vernacular English (AAVE) which her parents have claimed to have little or no knowledge of, her parents and the fieldworker coax her to give some examples, but she explains why it cannot be done, and her mother (R) elaborates:

$\mathrm{R}$ : So say something.

A: [[No: I don- I can't really say any now cause I'm not among people who=

C: [ [So say something yeah.

D: ( ) say something.

A: =speak, it just comes out ((laughs))." 
leń polonijnych, zmiany w artykulacji spółgłosek szczelinowych i zwarto-szczelinowych spowodowane brakiem fonemów palatalnych w języku angielskim. Nazywanie tego zjawiska seplenieniem nie jest trafne, ponieważ ów dyrektor - zapytany przeze mnie w prywatnej rozmowie - potrafił opisać, co ma na myśli. $Z$ tego samego powodu trudno też powiedzieć, że jest to określenie niepoprawne. Stosowanie pojęcia $z$ zakresu zaburzeń mowy, czyli właśnie „seplenienia”, na określenie tego typu interferencji nie jest zresztą rzadkie wśród rodziców dzieci i młodzieży polonijnej. Również w komentarzach fejsbukowych do wattku językowego pojawia się to zagadnienie, określane dokładnie tym samym terminem:

ja sama bardzo się staram mówić czysto po polsku, córka jeszcze bardziej (syn mniej ma okazji, ale mówi i bez seplenienia).

Zdaniem D.R. Prestona bardzo istotne jest analizowanie, w jaki sposób przeciętni użytkownicy języka charakteryzuja język, którym się posługują. Zaznacza, że niespecjaliści językowi używają do opisów swojej własnej terminologii, a to, co $z$ perspektywy językoznawcy wydaje się niepoprawne, może być jedynie kwestia zwykłej różnicy między słownictwem potocznym a specjalistycznym (trivial matter of labeling).

Przykład odwrotny, ukazujący relację między trafnością a szczegółowościa, dotyczy wymowy słów tutaj, dzisiaj realizowanej jako tutej, dzisiej. Wielokrotnie byłam świadkiem, jak imigranci pochodzący z rejonów miejskich ${ }^{17}$ próbowali objaśniać szczegółowo, że skoro mamy słowa tutejszy, dzisiejszy, to per analogiam powinniśmy mówić tutej, dzisiej i że jest to ich zdaniem wymowa wzorcowa. Choć można mówić o pewnej drobiazgowości w tłumaczeniu tego zjawiska językowego, to jednak $z$ językoznawczego punktu widzenia mamy do czynienia $z$ brakiem trafności naukowej.

Jeśli chodzi o trafność i umiejętność kontrolowania wariantów, trzeba zauważyć, że określony wariant języka może być powszechnie naśladowany, ale bardziej lub mniej nietrafnie. Dobrym przykładem jest zjawisko mazurzenia obecne w gwarze podhalańskiej. Przeciętny użytkownik języka uważa, że nie tylko $s z, c z, \dot{z}$ sa realizowane jako $s, c, z$, ale również zaliczaja do tego historyczne $r$ miękkie, czyli $r z$, które ma przecież inna geneze i nie podlega mazurzeniu.

Szczegółowość i umiejętność kontrolowania wariantów odnosi się do faktu, że przeciętny użytkownik języka może mieć znaczną kontrolę nad szczegółami danego wariantu językowego, który jednak może być mu dostępny tylko w stopniu ogólnym. Na przykład wiele osób potrafi naślado-

17 Formy typu tutej, dzisiej, wczorej sa uznawane za regionalizmy mazowieckie - tak mówili m.in. inteligenci warszawscy, np. prof. Jadwiga Rytel, specjalistka od literatury staropolskiej. Zdaniem B. Dunaja [1989], wymowa końcowego -aj jako -ej jest charakterystyczna m.in. dla gwar miejskich. 
wać obcy akcent, choćby niemiecki czy rosyjski, ale nie potrafi wyjaśnić szczegółowo, na czym ten akcent polega.

Te dwie ostatnie relacje, czyli trafności i umiejętności kontrolowania wariantów, a także szczegółowości i umiejętności kontrolowania wariantów, tworzą kontinua, a zdolność częściowej kontroli może odnosić się do spójności reprezentacji świadomości. W pewnym stopniu obie te relacje nakładaja się na siebie, ponieważ nie ma nic do kontrolowania poza detalami. Co więcej, nawet wyjaśnienia, jak te detale sa kontrolowane, bywaja mówiącemu w jakimś stopniu niedostępne lub są uznawane przez językoznawców za nietrafne.

\section{WNIOSKI}

D.R. Preston konkluduje zagadnienie wyznaczników potocznej świadomości językowej w następujący sposób: nie możemy ograniczać tego, co nazywamy świadomościa językową do jednej klasy czy jednego typu zachowań, np. postaw językowych (language attitude). Ktoś, kto potrafi ogólnie charakteryzować jakaśs odmianę języka, ma zdolność pełnej (gross) kategoryzacji różnic językowych dostępna jego świadomości, nawet jeśli nieumiejętność produkcji językowej lub charakteryzowania szczegółów przez mówiącego nie pozwala językoznawcy zmierzyć stopnia dokładności obserwacji.

Podejście do potocznej świadomości językowej, które proponuje D.R. Preston, ma charakter holistyczny, nie skupia się na wyodrębnianiu perspektyw psychologicznych, społecznych czy praktycznych, ale na ogólnym założeniu, że na świadomość językową składaja się zarówno kompetencja (językowa i komunikacyjna), jak i sprawność językowa. Potoczna świadomość językowa jest nie tylko sprawa stopnia, jak to jest w ujęciu M. Bugajskiego czy A. Markowskiego, ale również sposobu (mode). Warstwy świadomości językowej rozumiane tradycyjnie - czyli intuicja, wiedza szkolna lub zdroworozsądkowa [por. Dubisz 2017] oraz sady uzasadniane merytorycznie - moga podlegać eksplikacji pod względem tego, w jaki sposób uwidacznia się świadomość na poszczególnych poziomach. Jak pokazuja przykłady obrazujące technikę działania poszczególnych narzędzi do badania świadomości językowej, w każdym akcie produkcji językowej i percepcji językowej ujawnia się jakiś ułamek tej świadomości, chociaż niewattpliwie nadal otwartym pytaniem pozostaje precyzyjne zmierzenie sposobu i stopnia uzewnętrzniania świadomości. Każdy użytkownik języka ma niejako „swoja”, indywidualna potoczną świadomość językową, która jest ponadto różna $\mathrm{w}$ różnych kontekstach, a nawet $\mathrm{w}$ językach. To, czego przeciętny mówiący jest świadomy, jakie detale mieszczą się $\mathrm{w}$ jego świadomości, zależy przecież w większym stopniu od faktów socjolingwistycznych niż czysto lingwistycznych.

Warto ponownie podkreślić, że dla D.R. Prestona świadomość językowa to stopień uświadomienia, czy też uprzytomnienia sobie, jaki maja 
nielingwiści w odniesieniu do języka. Badacz nie neguje tradycyjnego rozumienia świadomości językowej ani też dorobku naukowego w tym zakresie, ale - jak powtarza za H. Hoenigswaldem [1966] - istotne jest, żeby wiedzieć nie tylko, czym język jest i jak ludzie go używają, ale istotne jest również to, co o nim myślą. W językoznawstwie potocznym bierze się pod uwagę zmiany w nomenklaturze używanej zarówno przez lingwistów, jak i nielingwistów, a następnie buduje $z$ nich dynamiczny kontekst aktualnego użycia, a nie statyczny model potocznej wiedzy językowej. Język stanowi tutaj obiekt badawczy nie tylko ze względu na swoją autoteliczność, ale także $z$ powodu niezaprzeczalnej wartości, jaka tkwi w interakcji badacza $z$ mówiącymi w odniesieniu do zasadniczych spraw człowieka, do których należy przede wszystkim język.

M. Sagan-Bielawa [2014], która w książce Dziedzictwo pozaborowe. Społeczna świadomość językowa używa określenia potoczna świadomość słusznie zauważa, że świadomości tej nie można wprawdzie brać za pewnik naukowy, ale też nie należy jej odrzucać jako bezwartościowej. Podkreśla jednocześnie, że zadaniem nauki jest tę świadomość zbadać, objaśnić, a nawet wykorzystać. Wydaje się, że scharakteryzowane wyżej wyznaczniki potocznej świadomości językowej mogłyby pomóc w realizacji tego postulatu również na gruncie polskim. Podjęcie próby przebadania świadomości językowej przy użyciu akcesorium D.R. Prestona mogłoby otworzyć nowe możliwości wglądu nie tylko w zawartość świadomości językowej przeciętnego użytkownika języka, ale również w sposoby, w jakich ta świadomość się ujawnia.

\section{Bibliografia}

J. Baudouin de Courtenay, 1915, Charakterystyka psychologiczna języka polskiego [w:] J. Łoś, J. Rozwadowski, A. Brückner, J. Baudouin de Courtenay, T. Benni (red.), Encyklopedya Polska, t. 2, dz. 3, cz. 1, Kraków, s. 154-268.

L. Bloomfield, 1944, Secondary and tertiary responses to language, „Language” 20, s. 45-55.

P. Bounds, 2015, Perceptual regions in Poland: An investigation of Poznań speech perceptions, „Journal of Linguistic Geography” 3, s. 34-45.

R. Carter, 2003, Language Awareness, „ELT Journal Volume” 57/1, s. 64-65.

D. Crystal, 2001, A Dictionary of Linguistics and Phonetics, Blackwell Publishers.

S. Cygan, 2002, Zagadnienie świadomości językowej w literaturze językoznawczej, „Annales Academiae Paedagogicae Cracoviensis”, Studia Linguistica 1, s. $47-57$.

S. Dubisz, 2017, Językoznawcze studia polonistyczne (pisma wybrane, uzupetnione, zmienione), t. V: Współczesna polszczyzna ogólna, Warszawa.

B. Dunaj, 1989, Język mieszkańców Krakowa, cz. I: Zagadnienia teoretyczne, fonetyka, fleksja, Kraków.

B. Dunaj, 1991, Dwa dyskusyjne problemy polskiej fonologii [w:] A. Kowalska, A. Wilkoń (red.), Prace językoznawcze 19. Studia polonistyczne, Katowice, s. $40-46$. 
A. van Essen, 1997, Language awareness and knowledge about language: An overview [w:] L. van Lier, D. Corson (red.), Encyclopedia of Language and Education, Vol. 6. Knowledge About Language, Dordrecht, s. 1-9.

N. Fairclough (red.), 1992, Critical Language Awareness, Harlow.

S. Gajda, 2004, O kulturze porozumiewania sie $w$ nauce [w:] K. Handke, H. Dalewska-Greń (red.), Polszczyzna a/i Polacy u schyłku XX w., Warszawa, s. 227-237.

H. Hoenigswald, 1966, A proposal for the study of folk-linguistics [w:] W. Bright (red.), Sociolinguistics. Proceedings of the UCLA Sociolinguistics Conference 1964, The Hague-Paris, s. 16-26.

P.E. Gębal, 2013, Modele kształcenia nauczycieli języków obcych w Polsce i w Niemczech. W strone glottodydaktyki porównawczej, Kraków.

K. Kłosińska, A. Hącia, S. Mandes, M. Adamczyk, K. Kiełpińska, 2017, Postawy wobec jezzkka. Raport $z$ badań przeprowadzonych $w$ ramach programu Ministerstwa Kultury i Dziedzictwa Narodowego „Obserwatorium Kultury” 20162017, Warszawa.

K. Maćkowiak, 2011, U źródeł polskiej świadomości językowej (X-XV wiek), Poznań.

K. Maćkowiak, 2020, Podstawowe problemy teorii świadomości językowej, „Poradnik Językowy" z. 2, s. 29-45.

A. Markowski, 2008a, Kultura języka polskiego, Warszawa.

A. Markowski, 2008b, Panel dyskusyjny: O świadomości językowej współczesnych Polaków [w:] J. Warchala, D. Krzyżyk (red.), Polska polityka językowa w Unii Europejskiej, Katowice, s. 219-243.

W. Miodunka, 2017, O potrzebie opisu i kształtowania świadomości językowej współczesnych Polaków, „Język Polski” XCVII, z. 3, s. 5-18.

W. Miodunka, 2020, Kształtowanie się świadomości językowej rodzimego użytkownika polszczyzny. Studium przypadku [w:] A. Burzyńska-Kamieniecka (red.), Język a Kultura 28, Wrocław [w druku].

N. Niedzielski, D.R. Preston, 2000, Folk Linguistics, Berlin-New York.

M. Paveau, 2007, Perceptual Norms in Folk Linguistics, "Langage et société" 1, 119, s. 93-109.

D.R. Preston, 1996, Whaddayaknow?: The Modes of Folk Linguistic Awareness, „Language Awareness” vol. 5, nr 1, s. 40-74.

M. Sagan-Bielawa, 2014, Dziedzictwo pozaborowe. Społeczna świadomość językowa Polaków w Drugiej Rzeczypospolitej, Kraków.

E. Sękowska, 1994, Język zbiorowości polonijnych w krajach anglojęzycznych. Zagadnienia leksykalno-słowotwórcze, Warszawa.

E. Sękowska, 1996, Wstęp [w:] Świadomość językowa-kompetencja-dydaktyka. Materiały ogólnopolskiej konferencji „Z badań nad kompetencją i świadomością językową dzieci i młodzieży”, Warszawa, 25-26 listopada 1994, Warszawa.

K. Stachowski, 2018, Przyczynek do dialektologii percepcyjnej Polski: Szczecin, „Język Polski” z. 1, s. 5-17.

S. Urbańczyk, M. Kucała (red.), 1999, Encyklopedia języka polskiego, Wrocław.

M. Wojtak, A. Siwiec, 1999, Świadomość stylistyczna na tle wybranych składników jej kontekstu pojęciowego [w:] J. Miodek (red.), Mowa rozświetlona myśla. Świadomość normatywno-stylistyczna współczesnych Polaków, Wrocław, s. 45-57. 


\section{How to examine folk linguistic awareness}

\section{Summary}

This paper presents the characteristics of the so-called folk linguistic awareness based on the assumptions of D.R. Preston and the American school of folk linguistics. This type of awareness is characterised by the following distinguishing features: explicit availability, degree of accuracy, level of detail, and ability to control various language variants. These determinants, which can be exemplified by the substance of the Polish language and the language used by the Polish community abroad, had not been used in the Polish research on linguistic awareness before.

Keywords: folk linguistic awareness - folk linguistics - language attitudes Polish community in Canada - determinants of awareness

Trans. Monika Czarnecka 